\title{
Mechanisms of Pleurodesis
}

\author{
Francisco Rodriguez-Panadero Ana Montes-Worboys \\ Unidad Médico-Quirúrgica de Enfermedades Respiratorias, Hospital Universitario Virgen del Rocío, \\ Instituto de Biomedicina de Sevilla, and CIBER Enfermedades Respiratorias, Sevilla, Spain
}

\author{
Key Words \\ Coagulation - Effusions - Pleurodesis - Sclerosing agents • \\ Systemic inflammation · Talc
}

\begin{abstract}
Pleurodesis aims to obliterate the pleural space by producing extensive adhesion of the visceral and parietal pleura, in order to control relapse of either pleural effusions (mostly malignant) or pneumothorax. A tight and complete apposition between the two pleural layers is a necessary condition to obtain a successful pleurodesis, but - besides this mechanical aspect - there are many biological mechanisms that appear to be common to most of the sclerosing agents currently used. Following intrapleural application of the sclerosing agent, diffuse inflammation, pleural coagulation-fibrinolysis imbalance (favoring the formation of fibrin adhesions), recruitment and subsequent proliferation of fibroblasts, and collagen production are findings in the pleural space. The pleural mesothelial lining is the primary target for the sclerosant and plays a pivotal role in the whole pleurodesis process, including the release of several mediators like interleukin-8, transforming growth factor- $\beta$ and basic fibroblast growth factor. When the tumor burden is high, normal mesothelial cells are scarce, and consequently the response to the sclerosing agent is decreased, leading to failure of pleurodesis. Also, the type of tumor in the pleural cavity may also affect the outcome of pleurodesis (diffuse malignant mesothelioma and metastatic lung carcinomas have a poor-
\end{abstract}

er response). There is general agreement that talc obtains the best results, and there are also preliminary experimental studies suggesting that it can induce apoptosis in tumor cells and inhibit angiogenesis, thus contributing to a better control of the malignant pleural effusion. There is concern about complications (possibly associated with talc but other agents as well) related to systemic inflammation and possible activation of the coagulation cascade. In order to prevent extrapleural talc dissemination, large-particle talc is recommended. Although it could - to some degree - interfere with the mechanisms leading to pleurodesis and a carefully balanced clinical decision has therefore to be made, prophylactic treatment with subcutaneous heparin is recommended during hospitalization (immediately before and after the pleurodesis procedure).

Copyright $\odot 2012$ S. Karger AG, Basel

\section{Introduction}

Pleurodesis is defined as the symphysis between the visceral and parietal pleura that prevents the accumulation of either air or liquid in the pleural space. Pleural fluid evacuation followed by pleurodesis is often attempted in patients with malignant pleural effusion (MPE) and

Previous article in this series: 1 . Anevlavis $\mathrm{S}$, Tzouvelekis A, Bouros D: Mechanisms of pleural involvement in orphan diseases. Respiration 2012;83:5-12.

\section{KARGER}

Fax +4161306 1234

E-Mail karger@karger.ch

www.karger.com
(C) 2012 S. Karger AG, Basel

0025-7931/12/0832-0091\$38.00/0

Accessible online at:

www.karger.com/res
Francisco Rodriguez-Panadero, MD

Edificio del Instituto de Biomedicina de Sevilla, Lab 120

Campus H.U. Virgen del Rocio, Avda. Manuel Siurot s/n

ES-41013 Sevilla (Spain)

Tel. +34955923 063, E-Mail frodriguezpan@gmail.com or frpanad@ono.com 
pneumothorax $[1,2]$. However, it can also be required in some benign effusions.

Most of the patients undergoing a pleurodesis procedure have symptomatic MPE. When this condition is diagnosed, palliative therapy should be considered with special evaluation of the patient's symptoms, general health, functional status and expected survival.

The main indication for treatment in such cases is to alleviate dyspnea, which is dependent on both the volume of the effusion and the underlying condition of the lungs and pleura. Therapeutic thoracentesis should be performed in virtually all dyspneic patients with MPE to determine its effect on breathlessness, and rate and degree of recurrence. This is especially important in patients presenting a massive pleural effusion and a contralateral mediastinal shift. Those particular cases are the obvious candidates for a pleurodesis procedure.

Management of the patients could vary according to their clinical condition. Thus, rapid recurrence of the effusion indicates the need for immediate treatment, and stability and absence of symptoms requires a closer follow-up.

According to the ATS/ERS consensus statement on the Management of Malignant Pleural Effusions [3], the following definitions were proposed for efficacious treatment.

\section{Successful Pleurodesis}

Complete Success. Long-term relief of symptoms related to the effusion, with absence of fluid reaccumulation on chest radiographs until death.

Partial Success. Diminution of dyspnea related to the effusion, with only partial reaccumulation of fluid (radiographic evidence of $<50 \%$ of the initial fluid), with no further therapeutic thoracentesis required during the follow-up.

Failed Pleurodesis. Lack of success as it is defined above.

Comparative studies of different pleurodesis techniques should evaluate outcome using time-to-event analyses and censor patients who are lost to follow-up. Data should be reported with and without inclusion of patients who die within 1 month of pleurodesis.

\section{Mechanisms Involved in Pleurodesis}

In order for pleurodesis to be successful, several conditions have to be taken into account.

\section{A Tight and Complete Apposition}

A tight and complete apposition between the visceral and parietal pleura is a sine qua non condition to accomplish a successful pleurodesis. This is not difficult to achieve in patients with pneumothorax and patients with no persistent air leak, but in cases of MPE, the situation could be more problematic, because the visceral pleura can become very thick and/or the lung parenchyma very stiff (due to diffuse tumor involvement), thus leading to uncompleted lung reexpansion. This phenomenon is termed trapped lung syndrome. Recently, different conditions provoking this problem have been reported in the literature. A study differentiated between 'trapped lung' caused by benign formation of a fibrous peel on the visceral pleura and 'lung entrapment', which would be secondary to active pleural inflammation, infection or malignancy. In these cases, the underlying malignant or inflammatory condition is the primary clinical problem, and placement of a chronic indwelling catheter should be considered in case of malignant effusion. Measurement of pleural fluid elastance during therapeutic thoracentesis is very helpful in differentiating those conditions [4].

\section{Inflammation}

After drainage of the pleural cavity, the two pleural layers are in contact. To maintain this union tight, fibrin adhesions and fibrotic tissue formation are needed. A complete pleural symphysis results when a strong irritation of the pleural surface is triggered following instillation of a chemical agent into the pleural space. Another approach is pleural decortication; however, this procedure is very aggressive for the patient. The underlying, common response in the pleural space after instillation of an irritating pleurodesis agent is inflammation. Activation of the inflammatory pathway leads to the required fibrotic state. Pleurodesis can also be achieved by abrading the pleural surface. This technique is often performed following surgical removal of blebs on the surface of the lung in pneumothorax patients, but apical talc pleurodesis has been shown to be more effective regarding recurrence prevention. In the initiation of the inflammatory process, normal pleural mesothelial cells are involved and activated by the pleurodesis process, and this eventually results in the development of symphysis between the visceral and parietal pleural surfaces. Following the instillation of talc, there is a rapid neutrophil influx into the pleural space that keeps increasing up to $24 \mathrm{~h}$. The chemokine interleukin-8 (IL-8) correlates with the neutrophil number counted in the pleural space, indicating that the sclerosant has initiated the release of neutrophil che- 
mokines in the pleural space [5]. After the recruitment of neutrophils, they secrete a variety of cytokines responsible for the perpetuation of the inflammatory pathway. The inflammatory response to the sclerosant can be significantly inhibited by corticosteroids [6], and - according to our knowledge - simultaneous steroid treatment is associated with an increased rate of pleurodesis failure in clinical practice.

\section{Coagulation Cascade and Decrease in the Pleural Fibrinolytic Activity}

A second critical response to a sclerosing agent is the initiation of the coagulation cascade and the decrease in the pleural fibrinolytic activity. This is necessary for the early formation of fibrin links between the visceral and parietal pleura, which further provoke the symphysis of the two pleural layers [7]. Agrenius et al. [8,9] demonstrated an increase in pleural coagulation and a decrease in fibrinolytic activity after the instillation of a sclerosing agent. It is assumed that the formation of a fibrin mesh is necessary for the recruitment and subsequent proliferation of fibroblasts in the pleural space. In this regard, we hypothesized a few years ago that either an impaired fibrin formation or an increase in endopleural fibrinolysis would lead to pleurodesis failure. Our group demonstrated that failure of talc pleurodesis is associated with an increased pleural fibrinolysis [10].

The formation of a fine latticework of fibrin (the end product of the coagulation cascade) between the visceral and parietal pleura initiates the third step of the inflammatory cascade. This process leads to the proliferation of fibroblasts, which form strong adhesive links between the visceral and parietal pleural surfaces, obliterating the pleural space [11]. At least in animal experiments, the initial fibroblast invasion of the fibrinous links between visceral and parietal pleura leads to the organization of wellvascularized and innervated connective tissue that resembles that of the undamaged pleura. Therefore, it appears that pleurodesis is not just a scar produced as a consequence of the repair process, but a structure establishing a functional continuity between both visceral and parietal pleura [12].

Several fibroblast growth factors have been found in the pleural fluid of patients given sclerosing agents. These include platelet-derived growth factor, basic fibroblast growth factor (bFGF) and transforming growth factor- $\beta$ (TGF- $\beta$ ). Patients with successful pleurodesis presented markedly increased levels of bFGF in the pleural fluid, and those with unsuccessful pleurodesis had significantly lower amounts of bFGF [13]. There appears to be a sig- nificant inverse correlation between the release of bFGF in the pleural fluid of patients who have MPE and tumor burden, as evaluated by objective grading during thoracoscopy. Thus, patients with extensive pleural tumor involvement do not have high levels of bFGF released by mesothelial cells. However, when talc is instilled early in the course of malignant pleural disease (thus pleural mesothelial cells remain extensively exposed to the sclerosing agent), the level of bFGF is much higher and pleurodesis successful. This is in agreement with clinical experience; thus, patients with advanced malignant pleural involvement have a worse outcome of treatment compared to those treated early in the course of their disease. Taken together, this indicates that an exuberant and vigorous response by pleural mesothelial cells is critical for the success of pleurodesis.

Mesothelial cells regulate the pleural coagulation-fibrinolysis balance and the first steps of the pleural fibrosis process [14]. Furthermore, there is a growing body of evidence concerning the association of fibrinolytic activity with tumor aggressiveness in other organs, thus suggesting that the strong fibrinolytic activity detected in our cases of pleurodesis failure arises, at least in part, from the neoplastic cells in the pleural space [15]. The normal pleura has an intrinsic fibrinolytic activity due to the production of both urokinase and tissue plasminogen activators by mesothelial cells, and this fibrinolytic activity is markedly increased in most of the MPE patients. In order to invade the surrounding tissue, tumor cells express huge amounts of plasminogen activators (fig. 1) that can be partially blocked by plasminogen activator inhibitors 1 and 2 (PAI-1 and PAI-2; fig. 2).

Fibrinolytic activity - expressed by D-dimer levels shows a decline $24 \mathrm{~h}$ after talc poudrage in patients who have successful pleurodesis. Moreover, D-dimer activity is not decreased after talc poudrage in patients with unsuccessful pleurodesis [9]. Commercial kits are already available to perform a rapid neutrophil count and D-dimer determination, and the measurement of those parameters will be a useful tool to monitor the ongoing biologic process after intrapleural talc instillation. Thus, patients developing a good inflammatory response show a typical pattern with rapidly increasing neutrophils and declining D-dimer activity in serial samples of pleural fluid after talc poudrage [16]. If this does not occur, or the response to talc is poor, we attempt to enhance the pleurodesis process by increasing the suction rate and prolonging the time of drainage in order to provoke a better pleural symphysis through mechanical irritation and tight apposition of the visceral and parietal pleura layers. 

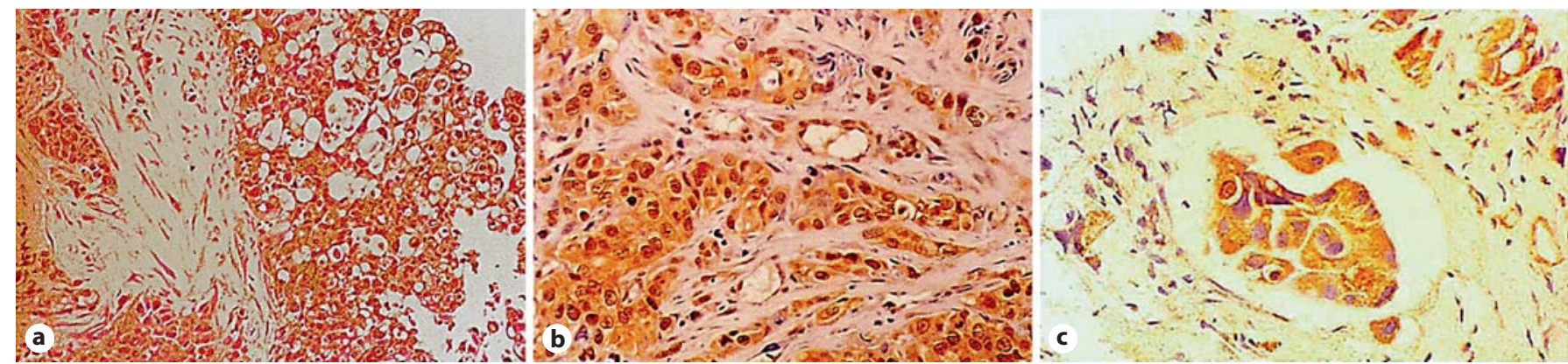

Fig. 1. Fibrinolytic activators expressed by tumor tissue in pleural metastatic carcinomas. a Marked expression of urokinase plasminogen activator by tumor cells in pleural metastatic carcinoma of the lung. This patient had a very short survival and failure of pleurodesis. $\mathbf{b}$ Expression of tissue plasminogen activator by tu-

mor cells in a patient with metastatic carcinoma of the lung, with short survival and poor outcome of pleurodesis. c Expression of urokinase plasminogen activator by tumor cells inside a lymphatic vessel and by other cells invading the surrounding pleural tissue.

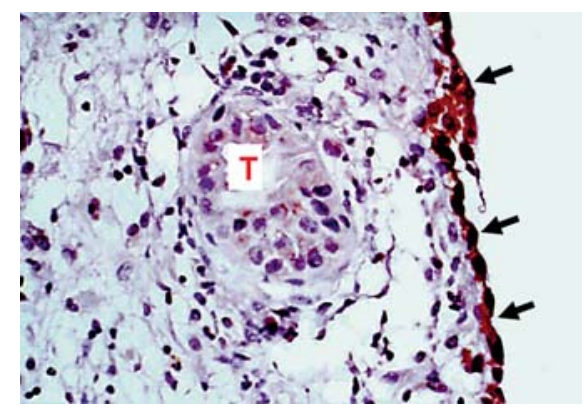

Fig. 2. PAI-2 expression by normal mesothelial cells (arrows) in a patient with metastatic carcinoma of the breast $(\mathrm{T})$. This patient had a long survival ( $>7$ years after talc poudrage) and very good results of pleurodesis.

\section{Role of the Mesothelium in Pleurodesis}

It was assumed that severe damage to the mesothelial layer was necessary to achieve a pleural symphysis. This is true when mechanical pleural abrasion or pleurectomy is performed, but there is increasing evidence for the new concept that the pleural mesothelium is the primary initiator of the biological mechanisms leading to pleurodesis $[17,18]$. We already know that the production/release of inflammatory and fibrosis markers by mesothelial cells are essential to achieve a good pleural symphysis, provided that mechanical conditions, as explained above, have been accomplished. In order to obtain satisfactory results, the sclerosing agent must reach the maximum surface area of normal mesothelium in the pleural space. Thus, when the mesothelial surface is covered by tumor or fibrin, and this circumstance is associated with low glucose and $\mathrm{pH}$ levels, the rate of failure is much higher [19-23]. This also explains why much lower doses of sclerosant are required to induce pleurodesis in pneumothorax (in which the mesothelial surface is almost completely preserved). In our thoracoscopy series, we found a complete successful talc pleurodesis in $79 \%$ of the patients with $\mathrm{pH} \geq 7.30$, whereas it was successful in only $40 \%$ of those with $\mathrm{pH}<7.20$, and in none of the patients with $\mathrm{pH}<7.15$ [17]. A low pleural $\mathrm{pH}$ has been associated with trapped lung and poor survival, and there are some clues suggesting that a low $\mathrm{pH}$ does not only mean that there is a thick visceral pleura with difficult lung reexpansion [24], but that it would also inhibit some of the biological processes leading to a good pleurodesis by itself.

The cellular mechanisms involved in pleurodesis are not yet fully understood, but it seems that - besides mesothelial cells - inflammatory cells recruited from the blood stream (neutrophils and mononuclear phagocytes) play an essential role [25]. There is also some evidence supporting the interaction between talc, as sclerosing agent, and its uptake in cells from the pleural space [26]; moreover, the specific surface area of the talc appears to have a marked influence on the outcome of pleurodesis. Thus, talcs with small particles have a higher specific surface area and then provoke more stimulation of mesothelial cells through extensive contact of the particles with the cell membrane. The cellular and biochemical mechanisms may be specific for the agent used for pleurodesis, but it seems that - in most of the cases - there is a common final pathway leading to the activation of the pleural 
Table 1. Outcome of pleurodesis in patients with pleural metastatic tumors of different origins after talc pleurodesis (source: our personal series)

\begin{tabular}{lcllc}
\hline $\begin{array}{l}\text { Tumor } \\
\text { origin }\end{array}$ & $\begin{array}{l}\text { Complete } \\
\text { success } \\
\mathrm{n}\end{array}$ & $\begin{array}{l}\text { Partial } \\
\text { success } \\
\mathrm{n}\end{array}$ & $\begin{array}{l}\text { Failure of } \\
\text { pleurodesis } \\
\mathrm{n}\end{array}$ & $\begin{array}{l}\text { Median survival } \\
\text { after pleurodesis } \\
\text { months }\end{array}$ \\
\hline Lung $(\mathrm{n}=109)$ & $72(66 \%)$ & $21(19 \%)$ & $16(15 \%)$ & $4.4(0.3-44)$ \\
Breast $(\mathrm{n}=95)$ & $74(78 \%)$ & $12(13 \%)$ & $9(9 \%)$ & $8.8(0.2-153)$ \\
Mesothelioma $(\mathrm{n}=69)$ & $41(59 \%)$ & $11(16 \%)$ & $17(25 \%)$ & $9.6(0.5-58)$ \\
Lymphoma $(\mathrm{n}=34)$ & $25(73 \%)$ & $6(18 \%)$ & $3(9 \%)$ & $11.8(0.3-137)$ \\
Ovary $(\mathrm{n}=26)$ & $20(77 \%)$ & $3(11.5 \%)$ & $3(11.5 \%)$ & $6.3(0.1-92)$ \\
Colon $(\mathrm{n}=19)$ & $16(85 \%)$ & $1(5 \%)$ & $2(10 \%)$ & $8.1(0.3-86)$ \\
Kidney $(\mathrm{n}=18)$ & $12(67 \%)$ & $4(22 \%)$ & $2(11 \%)$ & $3.4(0.1-12)$ \\
Stomach $(\mathrm{n}=13)$ & $9(69 \%)$ & $2(15.5 \%)$ & $2(15.5 \%)$ & $2.1(0.6-10)$ \\
Other origin $(\mathrm{n}=21)$ & $18(86 \%)$ & $2(9.5 \%)$ & $1(4.5 \%)$ & $3.5(0.6-98)$ \\
Sarcoma $(\mathrm{n}=7)$ & $4(57 \%)$ & $3(43 \%)$ & 0 & $2.1(0.8-10)$ \\
Unknown origin $(\mathrm{n}=49)$ & $35(71 \%)$ & $11(22 \%)$ & $3(7 \%)$ & $4.1(0.2-30)$ \\
Total $(\mathrm{n}=460)$ & $326(70.9 \%)$ & $76(16.5 \%)$ & $58(12.6 \%)$ & \\
\hline
\end{tabular}

coagulation cascade, the formation of fibrin networks and the proliferation of fibroblasts.

The recruitment and proliferation of fibroblasts in the pleural space are essential for the pleurodesis process, and there is evidence that both tetracycline and talc stimulate mesothelial cells to produce/release fibroblast growth factor $[27,28]$. It has been postulated that using TGF- $\beta_{2}$ for pleurodesis would induce effective - and faster than talc - pleurodesis in rabbits without provoking inflammation in the pleural space [29-31]. However (according to our knowledge), this agent has not yet been authorized for pleurodesis in humans.

\section{Outcome of Pleurodesis in Different Types of Tumors in the Pleura}

The role of the tumor type spreading to the pleural surfaces might determine the response to pleurodesis [32, 33]. In a combined two-center study evaluating the outcome of thoracoscopic talc poudrage and bedside doxycycline pleurodesis in different tumor types, we found that the type of tumor involving the pleural surfaces influences significantly the success of pleurodesis, regardless of the sclerosing agent used. Malignant effusion due to mesothelioma and lung cancer are particularly prone to induce the failure of pleurodesis, while outcome seems better in patients with breast or ovarian cancer. Similar good results were obtained with pleurodesis in lymphoma patients according to our talc pleurodesis series (ta- ble 1). A potential explanation could be that a trapped lung is relatively common in mesothelioma and metastatic tumors of the lung as a result of either visceral pleural restriction (mesothelioma) or endobronchial obstruction (lung cancer). Also, we found that a high tumor burden in the pleural space was negatively associated with the results of pleurodesis [34]. This indicates that the likelihood of achieving a successful pleurodesis decreases with an increasing pleural tumor burden observed during thoracoscopy. However, according to logistic regression analysis, tumor burden by itself did not account for the varying success rates of talc poudrage among the tumor groups in our study. Besides the above-mentioned mechanical explanation, other biological mechanisms may also be involved in the failure of pleurodesis (especially in mesothelioma), probably because the high tumor burden is jeopardizing the role that normal mesothelial cells would play in achieving a good pleural symphysis.

\section{The Choice of Sclerosants for Pleurodesis}

According to a Cochrane database [35] and another systematic review [36], talc is considered the best sclerosant for pleurodesis regarding the rate of success. In a randomized multicenter study, Dresler et al. [37] observed about the same overall efficacy for talc in 'poudrage' and 'slurry' forms, but they found that poudrage was better in pleural metastatic lung and breast carcinomas. In another randomized study comparing talc pou- 
drage and slurry, Mañes et al. [38] observed a higher rate of recurrences with talc in 'slurry' form than with poudrage. Other potential disadvantages of slurry include lack of uniform distribution and accumulation in adjacent areas of the pleural cavity, with subsequent incomplete pleurodesis and multiloculations. Also, we have observed that most of the talc administered in slurry form might be eventually eliminated through the chest tube after unclamping the drain [39].

In addition to inducing the best results in pleurodesis, recent studies seem to show a local antitumor effect of talc by triggering apoptosis in cancer cells [40] and by altering the angiostatic balance via endostatin [41]. Defective apoptotic signalling pathways have an important role in the initiation and progression of cancer, and they are related with tumor aggressiveness and short survival. If the above results are confirmed in larger series, talc would play a significant role in controlling not only pleural effusion but also intrapleural tumor progression.

Other agents that are gaining acceptance for pleurodesis are iodopovidone [42, 43] and silver nitrate [44]. Instillation of doxycycline through a small-bore catheter is also a good choice for bedside pleurodesis [45], although intrapleural injection of lidocaine prior to the procedure and premedication to alleviate anxiety and pain are mandatory in this case.

\section{Mechanisms Associated with Complications of Pleurodesis}

Thoracoscopy is associated with a transient impairment in lung function, which is more pronounced when pleurodesis is performed [46]. With the exception of some complications related to the technique itself [47], which could be prevented using ultrasound examination, the most relevant are systemic complications associated with intrapleural instillation of the sclerosant.

\section{Acute Respiratory Distress or Pneumonitis}

This has been described in some cases of talc pleurodesis $[48,49]$, but the pathophysiologic mechanism responsible for this severe complication is still unclear. A cause of concern is systemic inflammation, which apparently commonly occurs following instillation of almost all agents into the pleural space [50] and administration of talc-containing small particles $(<10 \mathrm{~mm}$ in diameter) [51]. A large European multicenter study on the safety of talc poudrage including 558 patients with MPE treated with $4 \mathrm{~g}$ of large-particle talc (median diameter: $25.6 \mathrm{~mm}$ ) found no cases of acute respiratory distress [52]. On the contrary, in a recent study from a North American center, talc-related lung injury was noted in 4 of 143 procedures $(2.8 \%)$, and talc exposure might have contributed to the respiratory deterioration in 4 additional patients [53]. The talc used for this study (the only one approved by the US Food and Drug Administration for intrapleural instillation) had a smaller particle size than the one most frequently used in Europe [54]. Acute respiratory complications arise more frequently in patients with poor clinical condition at the time of pleurodesis, and careful evaluation of the performance status of those patients prior to thoracoscopy and pleurodesis is therefore highly recommended.

\section{Possible Activation of Systemic Coagulation after Pleurodesis}

There is evidence that thoracoscopy - like many other interventional procedures - can provoke systemic inflammation, but it is clear that talc pleurodesis induces a stronger reaction in many cases $[55,56]$. In an experimental study on talc slurry treatment in rabbits, prominent perivascular infiltrates were found in the underlying lung, and the authors speculated that some mediators might spread from the pleura to the pulmonary circulation [57].

As quoted elsewhere in this article, coagulation was increased and fibrinolytic activity was decreased in the pleural space after intrapleural application of talc. If systemic inflammation is concurrently present, the possible systemic implications of the pleural coagulation-fibrinolysis imbalance involved in the pleurodesis process itself might be the cause of concern. Prompted by this concern and by several cases of massive pulmonary embolism after talc pleurodesis, we concomitantly determined pleu$\mathrm{ral} /$ plasma markers of coagulation and fibrinolysis and found that activation of systemic coagulation is frequently observed after talc poudrage [58], and that this side effect can be partially controlled with prophylactic heparin [59].

We have recently reported that IL- 8 , which is increased in the pleural fluid after talc treatment, activates the coagulation cascade and correlates with survival after talc pleurodesis [60]. The relevance of this finding in clinical practice is still unclear, but some premature deaths following pleurodesis may be in part related to undetected thrombosis and/or pulmonary embolism, and not only to advanced neoplastic disease, as it is commonly believed. This concern applies not only to talc, but also to other sclerosants [Rodriguez-Panadero, unpubl. results], and 
we therefore advise - despite some possible impairment in the mechanisms leading to pleurodesis [61] - giving subcutaneous prophylactic heparin to patients who are submitted to pleurodesis during the whole hospitalization period.

\section{Conclusion}

In summary, the pleural mesothelial cell is the primary target for the sclerosant and plays a pivotal role in the whole pleurodesis process, including diffuse inflammation, pleural coagulation-fibrinolysis imbalance (favoring the formation of fibrin adhesions), fibroblast recruitment, and subsequent proliferation and production of collagen after intrapleural application of the sclerosing agent. When the tumor burden is high, normal mesothe- lial cells are scarcely present, and then the response to the sclerosing agent is lower, leading to failure of pleurodesis. Complications associated with pleurodesis might be minimized using large-particle talc and prophylactic treatment with subcutaneous heparin during hospitalization. However, it should be borne in mind that heparin prophylaxis could interfere - to some degree - with the mechanisms leading to a successful pleurodesis, and the pros and cons have to be balanced in clinical decision making.

\section{Acknowledgments}

We thank Dr. Lourdes Gomez-Izquierdo for figures 1 and 2. Part of the work quoted in this article was supported by grants (FIS 98/0419, FIS 01/0595 and FIS 04/0289 from the Instituto de Salud Carlos III, Spain).

\section{References}

$\checkmark 1$ Froudarakis ME: New challenges in medical thoracoscopy. Respiration 2011;82:197-200.

$\checkmark 2$ Rodriguez-Panadero F: Medical thoracoscopy. Respiration 2008;76:363-372.

-3 Antony VB, Loddenkemper R, Astoul P, Boutin C, Goldstraw P, Hott J, et al: Management of malignant pleural effusions. Eur Respir J 2001;18:402-419.

4 Huggins JT, Doelken P, Sahn SA: The unexpandable lung. F1000 Med Rep 2010;2:77.

5 Hartman DL, Antony VB, Hott JW, Godbey SW, Yu L, Rodriguez Panadero F: Thoracoscopic talc insufflation increases pleural fluid IL-8 levels in patients with malignant pleural effusions. Am J Respir Crit Care Med 1994;149(suppl 2):A974.

-6 Xie C, Teixeira LR, McGovern JP, Light RW: Systemic corticosteroids decrease the effectiveness of talc pleurodesis. Am J Crit Care Med 1998;157:1441-1444.

-7 Mutsaers SE, Prele CM, Brody AR, Idell S: Pathogenesis of pleural fibrosis. Respirology 2004;9:428-440.

$>8$ Agrenius V, Chmielewska J, Widström O, Blombäck M: Increased coagulation activity of the pleura after tube drainage and quinacrine instillation in malignant pleural effusion. Eur Respir J 1991;4:1135-1139.

-9 Agrenius V, Chmielewska J, Widström O, Blombäck M: Pleural fibrinolytic activity is decreased in inflammation as demonstrated in quinacrine pleurodesis treatment of malignant pleural effusion. Am Rev Respir Dis 1989;140:1381-1385.

10 Rodriguez-Panadero F, Segado A, Martin Juan J, Ayerbe R, Torres Garcia I, Castillo J:
Failure of talc pleurodesis is associated with increased pleural fibrinolysis. Am J Respir Crit Care Med 1995;151:785-790.

$\checkmark 11$ Antonangelo L, Vargas FS, Teixeira LR, Acencio MM, Vaz MA, Filho MT, Marchi E: Pleurodesis induced by talc or silver nitrate: evaluation of collagen and elastic fibers in pleural remodeling. Lung 2006;184:105-111.

12 Montes JF, Garcia-Valero J, Ferrer J: Evidence of innervation in talc-induced pleural adhesions. Chest 2006;130:702-709.

13 Antony VB, Nasreen N, Mohammed KA, Sriram PS, Frank W, Schoenfeld N, et al: Talc pleurodesis: basic fibroblast growth factor mediates pleural fibrosis. Chest 2004;126: 1522-1528.

14 Jantz MA, Antony VB: Pathophysiology of the pleura. Respiration 2008;75:121-133.

15 Rodriguez Panadero F, Gómez Izquierdo L, Martin Juan J, Borderas F, Sánchez JF, Segura DI: The balance between expression of plasminogen activators and their inhibitor (PAI-1) in pleural tissue is associated to outcome of talc pleurodesis. Am J Resp Crit Care Med 1997;155:A739.

16 Psathakis K, Calderon-Osuna E, RomeroRomero B, Martín-Juan J, Romero-Falcón A, Rodríguez-Panadero F: The neutrophilic and fibrinolytic response to talc can predict the outcome of pleurodesis. Eur Respir J 2006;27:817-821.

17 Rodriguez-Panadero F, Antony VB: Pleurodesis. State of the art. Eur Respir J 1997;10: 1648-1654.

18 Marchi E, Vargas FS, Acencio MM, Antonangelo L, Genofre EH, Teixeira LR: Evi- dence that mesothelial cells regulate the acute inflammatory response in talc pleurodesis. Eur Respir J 2006;28:929-932.

19 Sahn SA, Good JT Jr: Pleural fluid pH in malignant effusions: diagnostic, prognostic and therapeutic implications. Ann Intern Med 1988;108:345-349.

20 Rodriguez-Panadero F, Lopez Mejias J: Low glucose and $\mathrm{pH}$ levels in malignant pleural effusions: diagnostic significance and prognostic value in respect to pleurodesis. Am Rev Respir Dis 1989;139:663-667.

21 Sanchez-Armengol A, Rodriguez-Panadero F: Survival and talc pleurodesis in metastatic carcinoma revisited. Report on 125 cases. Chest 1993;104:1482-1485.

22 Rodriguez-Panadero F, Romero-Romero B: Management of malignant pleural effusions. Curr Opin Pulm Med 2011;17:269273.

23 Martinez-Moragon E, Aparicio J, Sanchis J, Menendez R, Cruz Rogado M, Sanchis F: Malignant pleural effusion: prognostic factors for survival and response to chemical pleurodesis in a series of 120 cases. Respiration 1998;65:108-113.

24 Aelony Y, Yao JF, King RR: Prognostic value of pleural fluid $\mathrm{pH}$ in malignant epithelial mesothelioma after talc poudrage. Respiration 2006;73:334-339.

25 Antony VB, Hott JW, Kunkel SL, Godbey SW, Burdick MD, Strieter RM: Pleural mesothelial cell expression of C-C (monocyte chemotactic peptide) and C-X-C (interleukin 8) chemokines. Am J Respir Cell Mol Biol 1995 ; 12:581-588. 
26 Hartman DL, Harper-Allen PJ, Godbey SW, Hott JW, Yu L, Antony VB: Phagocytosis of talc particles by human pleural mesothelial cells (HPMC) correlates with IL-8 production. Am J Respir Crit Care Med 1994;148:A845.

-27 Antony VB, Rothfuss KJ, Godbey SW, Sparks JA, Hott JW: Mechanism of tetracycline hydrochloride-induced pleurodesis: tetracycline hydrochloride-stimulated mesothelial cells produce a growth factor-like activity for fibroblasts. Am Rev Respir Dis 1992;146: 1009-1013.

28 Godbey SW, Holm KA, Yu L, Hott JW, Rodriguez-Panadero F, Antony VB: Role of mesothelial cells in pleural fibrosis following successful talc poudrage: identification of basic fibroblast growth factor (FGF-2) in pleural fluids. Am J Respir Crit Care Med 1995; 151:A353.

-29 Light RW, Cheng DS, Lee YC, Rogers J, Davidson J, Lane $\mathrm{KB}$ : A single intrapleural injection of transforming growth factor- $\beta_{2}$ produces an excellent pleurodesis in rabbits. Am J Respir Crit Care Med 2000;162:98-104.

- 30 Gary Lee YC, Teixeira LR, Devin CJ, Vaz MA, Vargas FS, Thompson PJ, et al: Transforming growth factor- $\beta_{2}$ induces pleurodesis significantly faster than talc. Am J Respir Crit Care Med 2001;163(3 pt 1):640-644.

- 31 Lee YC, Lane KB, Zoia O, Thompson PJ, Light RW, Blackwell TS: Transforming growth factor-beta induces collagen synthesis without inducing IL-8 production in mesothelial cells. Eur Respir J 2003;22:197-202.

- 32 Kolschmann S, Ballin A, Gillissen A: Clinical efficacy and safety of thoracoscopic talc pleurodesis in malignant pleural effusions. Chest 2005;128:1431-1435.

33 Viallat JR, Rey F, Astoul P, Boutin C: Thoracoscopic talc poudrage pleurodesis for malignant effusions. A review of 360 cases. Chest 1996;110:1387-1393.

- 34 Bielsa S, Hernandez P, Rodriguez-Panadero F, Taberner T, Salud A, Porcel JM: Tumor type influences the effectiveness of pleurodesis in malignant effusions. Lung 2011;189: 151-155.

35 Shaw P, Agarwal R: Pleurodesis for malignant pleural effusions. Cochrane Database Syst Rev 2004;1:CD002916.

-36 Tan C, Sedrakyan A, Browne J, Swift S, Treasure T: The evidence on the effectiveness of management for malignant pleural effusion: a systematic review. Eur J Cardiothorac Surg 2006;29:829-838.

- 37 Dresler CM, Olak J, Herndon JE, Richards WG, Scalzetti E, Fleishman SB, et al: Phase III intergroup study of talc poudrage vs. talc slurry sclerosis for malignant pleural effusion. Chest 2005;127:909-915.
38 Mañes N, Rodriguez-Panadero F, Bravo JL, Hernández Rodríguez $\mathrm{H}$, Alix Trueba $\mathrm{A}$ : Talc pleurodesis: prospective and randomized study. Clinical follow-up. Chest 2000; 118(4 suppl):131S.

39 Rodriguez-Panadero F, Jannsen JP, Astoul P: Thoracoscopy: general overview and place in the diagnosis and management of pleural effusion. Eur Respir J 2006;28:409-421.

40 Nasreen N, Mohammed KA, Dowling PA, Ward MJ, Galffy G, Antony VB: Talc induces apoptosis in human malignant mesothelioma cells in vitro. Am J Respir Crit Care Med 2000;161(2 pt 1):595-600.

41 Nasreen N, Mohammed KA, Brown S, Su Y, Sriram PS, Moudgil B, Loddenkemper R, Antony VB: Talc mediates angiostasis in malignant pleural effusions via endostatin in duction. Eur Respir J 2007;29:761-769.

42 Neto JD, de Oliveira SF, Vianna SP, Terra RM: Efficacy and safety of iodopovidone pleurodesis in malignant pleural effusions. Respirology 2010;15:115-118.

43 Mohsen TA, Zeid AA, Meshref M, Tawfeek N, Redmond K, Ananiadou OG, et al: Local iodine pleurodesis versus thoracoscopic talc insufflation in recurrent malignant pleural effusion: a prospective randomized control trial. Eur J Cardiothorac Surg 2011;40:282286.

44 Terra RM, Kim SY, Pego-Fernandes PM, Teixeira LR, Vargas FS, Jatene FB: Is silver nitrate pleurodesis for patients with malignant pleural effusion feasible and safe when performed in an outpatient setting? Ann Surg Oncol 2011;18:1145-1150.

45 Porcel JM, Salud A, Nabal M, Vives M, Esquerda A, Rodríguez-Panadero F: Rapid pleurodesis with doxycycline through a small-bore catheter for the treatment of metastatic malignant effusions. Support Care Cancer 2006;14:475-478.

46 Froudarakis ME, Pataka A, Makris D, Kouliatsis G, Anevlavis S, Sotiriou I, et al: Respiratory muscle strength and lung function in patients undergoing medical thoracoscopy. Respiration 2010;80:220-227.

47 Bosch-Barrera J, Espinós J: Hepatic breast cancer dissemination after an iatrogenic hepatic laceration during talc pleurodesis: a case report. Int Arch Med 2010;3:6.

48 Rinaldo JE, Owens GR, Rogers RM: Adult respiratory distress syndrome following intrapleural instillation of talc. J Thorac Cardiovasc Surg 1983;85:523-526.
49 Rehse DH, Aye RW, Florence MG: Respiratory failure following talc pleurodesis. Am J Surg 1999;177:437-440.

50 Ukale V, Agrenius V, Widström O, Hassan A, Hillerdal G: Inflammatory parameters after pleurodesis in recurrent malignant pleural effusions and their predictive value. Respir Med 2004;98:1166-1172

-51 Maskell NA, Lee YC, Gleeson FV, Hedley EL, Pengelly G, Davies RJ: Randomized trials describing lung inflammation after pleurodesis with talc of varying particle size. Am J Respir Crit Care Med 2004;170:377-382.

-52 Janssen JP, Collier G, Astoul P, Tassi GF, Noppen M, Rodriguez-Panadero F, et al: Safety of talc poudrage in malignant pleural effusion. Lancet 2007;369:1535-1539.

53 Gonzalez AV, Bezwada V, Beamis JF Jr, Villanueva AG: Lung injury following thoracoscopic talc insufflation: experience of a single North American center. Chest 2010;137: 1375-1381.

-54 Ferrer J, Villarino MA, Tura JM, Traveria A, Light RW: Talc preparations used for pleurodesis vary markedly from one preparation to another. Chest 2001;119:1901-1905.

55 Froudarakis ME, Klimathianaki M, Pougounias M: Systemic inflammatory reaction after thoracoscopic talc poudrage. Chest 2006;129:356-361.

56 Genofre EH, Marchi E, Vargas FS: Inflammation and clinical repercussions of pleurodesis induced by intrapleural talc administration. Clinics (Sao Paulo) 2007;62:627-634.

$\checkmark 57$ Kennedy L, Harley RA, Sahn SA, Strange C: Talc slurry pleurodesis: pleural fluid and histologic analysis. Chest 1995;107:1707-1712.

58 Rodriguez-Panadero F, Segado A, Torres I, Martin J, Sanchez J, Castillo J: Thoracoscopy and talc poudrage induce an activation of the systemic coagulation system. Am J Respir Crit Care Med 1995;151:A357.

59 Rodriguez-Panadero F, Segado A, Martin Juan J, Sánchez J, Calderón E, Castillo J: Activation of systemic coagulation in talc poudrage can be (partially) controlled with prophylactic heparin. Am J Respir Crit Care Med 1996;153:A458.

60 Montes-Worboys A, Rodriguez-Portal JA, Arellano-Orden E, Digón-Pereiras J, Rodriguez-Panadero F: Interleukin-8 activates coagulation and correlates with survival after talc pleurodesis. Eur Respir J 2010;35:160166.

61 Strange C, Baumann MH, Sahn SA, Idell S: Effects of intrapleural heparin or urokinase on the extent of tetracycline-induced pleural disease. Am J Respir Crit Care Med 1995;151: 508-515. 


\section{Erratum}

In the article by Rodriguez-Panadero and Montes-Worboys, entitled 'Mechanisms of Pleurodesis' [Respiration 2012;83:91-98], millimeters (mm) were used instead of micrometers $(\mu \mathrm{m})$. The correct text on page 96 , left column, last paragraph should read as follows:

Acute Respiratory Distress or Pneumonitis

This has been described in some cases of talc pleurodesis [48, 49], but the pathophysiologic mechanism responsible for this severe complication is still unclear. A cause of concern is systemic inflammation, which apparently commonly occurs following instillation of almost all agents into the pleural space [50] and administration of talc-containing small particles $(<10 \mu \mathrm{m}$ in diameter) [51]. A large European multicenter study on the safety of talc poudrage including 558 patients with MPE treated with $4 \mathrm{~g}$ of large-particle talc (median diameter: $25.6 \mu \mathrm{m}$ ) found no cases of acute respiratory distress [52]. 